\title{
ANALYZING THE REGIONAL DEVELOPMENT OF KURDISH BORDER CITIES OF IRAN USING SUSTAINABLE URBAN DEVELOPMENT INDICES (STUDY AREA: KURDISTAN PROVINCE)
}

\author{
Akbar HEYDARI* \\ Ferdowsi University of Mashhad, Faculty of Letters \& Humanities, Department \\ of Geography, Park Square, 9177948974, Mashhad, Iran e-mail: heydariakbar@um,.ac.ir

\section{Soheila BAKHTAR} \\ University of Tabriz, Department of-Geography \& Rural Planning, Tabriz, Iran \\ e-mail: soheyla.bakhtar@yahoo.com
}

\begin{abstract}
Citation: Heydari, A., \& Bakhtar, S. (2018). ANALYZING THE REGIONAL DEVELOPMENT OF KURDISH BORDER CITIES OF IRAN USING SUSTAINABLE URBAN DEVELOPMENT INDICES (STUDY AREA: KURDISTAN PROVINCE). GeoJournal of Tourism and Geosites, 23(3), 797-807. https://doi.org/10.30892/gtg.23315-329
\end{abstract}

\begin{abstract}
Access to welfare services and social, infrastructural, cultural, and educational facilities is one of the major indicators of development in any planning unit. Hence, the analysis and comparison of access to these facilities are considered as one of the most important factors in determining the degree of development in each society. In order to, the main goal of this research was analyzing the regional development of Kurdistan province using sustainable urban development indices. This research is an applied study with respect to its goal, and a descriptive-analytical study with respect to its nature. It was also predominantly carried out with a quantitative approach. The statistical population for this research included 10 cities of Kurdistan province that were ranked using six indices in the form of 61 criteria extracted from the 2016 statistical yearbook. Analyses were conducted using the VIKOR, TOPSIS, SAW, and Copeland techniques to integrate the results. The findings show that the cities of Kurdistan province are not in a good status in terms of the development indices, and there are large disparities in these cities in the economic, infrastructural, educational, health, cultural, and well-being dimensions, so that only the Sanandaj city was considered as a developed area. Also, four cities were semi-privileged (halfdeveloped), while five cities were deprived of development.
\end{abstract}

Key words: Regional Development, Urban Development, Decision-making Techniques, Kurdistan Province

\footnotetext{
* Corresponding author
} 


\section{INTRODUCTION}

By the end of the 1990 s, approximately $15 \%$ of the earth's population were living in urban areas (Badiali et al., 2018). The statistics increased considerably in the $20^{\text {th }}$ century, and it is estimated that over $90 \%$ of the world population will live in cities by 2100 and the urban world will change the dominant identity of the geographical spaces (Carreon \& Worrell, 2018; Fragkias et al., 2013). A major transformation will also occur in the harvest of resources, and as areas occupying less than $5 \%$ of the earth's surface area, cities will consume $80 \%$ of the resources, replacing the producer space with the dense demographic space (Carreon \& Worrell, 2018). This trend has posed several challenges to cities as the centers for capital accumulation and economic power. Therefore, the unsatisfactory distribution of spatial facilities and different levels of access to development indices is serious warnings to urban planners about overcoming the existing challenges and increasing the potentials for urban development (UNEP, 2015; Barrera et al., 2018; Ghaedi Rahmati et al., 2013). In these countries, the levels of development have been influenced by drastic regional disparities due to the rapid asymmetric growth, lack of proportional development in the region, uncontrolled allocation of resources and facilities to the privileged regions, and deprivation of other regions. These disparities are increasing in some areas, resulting in underdevelopment in all dimensions (Nazmfar et al., 2015; Venkatesh, 2002). In these countries, one or two regions are privileged in terms of access to public services and thus play a substantial role in the national product and revenue.

This has resulted in the underdevelopment of other regions and has increased disparities between regions and districts (Lotfi \& Shabani, 2012; Ela \& Schwartz, 2006; Soleymani et al., 2016; Sasanpour et al., 2015). In Iran, the human development reports discuss these differences and disparities and introduce the concern for spatial planning as one of the most important human development policies and a long-term plan for social justice and regional balance (Taghvayi et al., 2011). Moreover, due to the Regional inequality in Iran, the development gap between the developed and deprived regions grows increasingly, while economic and social justice loses its meaning (Husseinzaeh Dalir, 2013). The studies on the deprived regions and the comprehensive development studies on various parts and regions of Iran in the past decades are among the extensive operational actions serving this purpose (Mirzakhani \& Barandak, 2014).

This is because the identification and clarification of different levels of regional development and the identification of their weaknesses and strengths are of great importance to planning. In addition, disparity reduction and utilization of the resources, achievements, and facilities of societies are among the major criteria for development (Taghvayi \& Ghaedrahmati, 2006; Safaypour \& Shanbehpour, 2016). Currently, one of the major planning problems in Iran is the imbalance caused by the distribution of facilities in provinces and cities, which has disabled and impaired the balance of the urban network (Nemati et al., 2014). This is because development and its infrastructure have caused drastic changes to the development of various parts of Iran due to the unsatisfactory and centralized national plans of the past (Zareh \& Zadilak, 2011; Yu et al., 2010). Kurdistan province is one of the country's deprived regions in terms of having the development indices. Hence, the analysis of various educational, infrastructural, and health dimensions and the shortages in these dimensions in the cities of this province are among the factors necessitating the investigations into this issue in this province. The problem discussed in this research is the assessment of the distribution of facilities and services in this province with respect to the development indices. It is also attempting to identify the cities that are considered privileged and 
deprived in terms of having the development indices. Finally, it is trying to use the results from this research to identify the spatial investment priorities for balanced development and organization and reduced inequality.

\section{Literature review and theoretical background}

As a notion connoting excellent, development is the fruit of long-term evolutions (UN, 2011). It has changed with the public needs and demands by virtue of economic, social, and environmental conditions in the modernization process (Michael, 2014). Hence, given that the notion of development is a general notion its actualization relies on concurrent successes in areas such as drastic economic growth, acquisition of vast technical knowledge, achievement of spatial balance on the local, regional, and national levels, establishment of social and economic welfare, cultural promotion of people and groups, and attempts at constant modernization of society and enhancement of social and economic relations (Saeedi, 1998; Anabestani et al., 2014). Various theories such as the growth and economic development theory, modernization sociologic theory, Marxism and Neo-Marxism theories, post-structuralism, post-development theory, postcolonial theory, and feminist development theories, which explain the development of the global and national levels, are involved in the analysis of development and underdevelopment.

The first fundamental theory of development and underdevelopment was put forward in the 1950s, while various schools and viewpoints (Badri et al., 2006) on the establishment of social and economic justice were voiced to eradicate inequality, optimally distribute the resources, and provide for the balanced growth of the regions (Houghton \& Counsel, 2004). One of the theories advanced to increase the understanding of development and its related phenomena (such as welfare and income inequality) was a John Friedman's core-periphery theory, which is proposed as a general model of economic development and the interwoven regional planning strategies to provide a simple model and measure of regional development in the underdeveloped countries (Dehghani \& Rayati Showazi, 2011). The dependency theory was produced in response to the conventional development theories in the 1950s, when new countries suffering from underdevelopment emerged, introducing the simulation of the capitalist institutions as the key to development (Salimi, 2012). It consists of two main movements: The first movement was the Marxists movement, which suggested that underdevelopment was rooted in the class conflict caused by capitalism and led to the exploitation of the third world countries. The second viewpoint advocated the convergence theory. In their attempt to achieve similar levels of economic development, countries converge by one or several criteria, reaching a state of stability (Anton, 2006). Neo-Keynesians believe development is export-dependent. They split the regional economy into the basic and non-basic parts and believe development is born of the basic part (Harvey, 1996). Neoclassic economists also argue that growth and development are influenced by the balance and displacement mechanisms, which result in a free flow of resources between the regions in an area or country or the establishment of inter-regional balance in the long run (Li \& Wei, 2010).

The satisfaction of fundamental needs, the reduced economic inter-regional disparities, access of most deprived groups to public services, and increased public participation in the economic, social, and political processes have been the top priorities of development since the 1970s due to the failure of the traditional development strategies in reducing disparity and bringing about balanced regional development. Governments must also adopt the growth and equality policies more than ever and strategies such as participatory development, integrated, development, and down-top development (Tavakoli et al., 2014) must be put into practice. This is because today no development theorist emphasizes its one-dimensional nature and its economic, social, political, and cultural 
aspects are also acknowledged (Sasanpour et al., 2011). Through a brief review of the development and underdevelopment theories, these theories can be classified into two major categories: 1) fundamental development frameworks) modern development frameworks. The evolutionary development school, modernization theories, and Marxist development theory fall into the fundamental frameworks category (Safaypour \& Shanbehpour, 2016). On the other hand, the modern development frameworks, which advocate notions such as local communities, the role of nonpublic organizations, gender-, justice-, and democracy-related issues, citizenship participation, environment, and sustainable development, rely on the bottom-up participation approach (Hataminezhad et al., 2017). They change the government's role as the primary builder, provider, and regulator to the developer of powerful frameworks, granter of power, and motivator of collaboration based on the notion of populism in the sustainable development theory (Montazer, 2008).

\section{MATERIAL \& METHODS}

The present research is an applied study as regards its objective and a descriptiveanalytical study with respect to its nature. It was also conducted by adopting a quantitative approach. The statistical population for this research included 10 cities of Kurdistan Province. The data were collected using the desk research method and the tables included in the statistical books. Hence, six indices were used in the form of 61 economic, educational, infrastructural, health, therapeutic, and welfare criteria extracted from the Population and Housing Census of 2016 and 2015 statistical yearbook (Table 1).

The norm method was employed to standardize these indices, and through the Shannon entropy a weight was assigned to each index. The entropy coefficient varied between zero and one. As the value approached one, the distribution was more just, and as it approached zero the distribution was more imbalanced. Entropy is an unstable measure of the balance of a distribution. As this index grows, the distribution moves toward a state of equilibrium (Dadashpour \& Moloodi, 2011: 110). The multiple criteria decision-making models (SAW, TOPSIS, and VIKOR) were used to analyze the data and measure the development of the province's cities. VIKOR is a multiple criteria problemsolving method used to solve problems with incongruent criteria when the decision maker needs a near-ideal solution. On the other hand, this method can function as an effective decision-making tool when the decision maker is not capable of identifying and expressing the superiority of a problem in the beginning and also designing it. The difference between this model and the hierarchical or network-based decision-making models is that in this model, no pairwise comparison is carried out between the criteria and options, and each option is independent and assessed against a criterion.

In TOPSIS, the selected indicator must have the shortest distance from the positive ideal and the longest distance from the negative ideal. In this method, the preference of each index must increase or decrease uniformly. In other words, the best existing value of an indicator shows a positive ideal, whereas the worst value shows a negative ideal. Finally, the options are ranked according to the shortest distance from the positive ideal and the longest distance from the negative ideal. SAW is the simplest multiple criteria decision-making technique. In this method, which is known as the linear weighted combination ranking technique, after normalizing the decision matrix, the weighted normalized decision matrix is obtained using the criteria weighted coefficients, and based on this matrix, the score of each option is calculated. Copeland technique was used to obtain equal ranks using a combination of ranks resulted from the decision-making techniques. Copeland is an integration technique in which the number of victories and defeats for each option is calculated in the prioritization 
Analyzing the Regional Development of Kurdish Border Cities of Iran Using

Sustainable Urban Development Indices (Study Area: Kurdistan Province)

process. To this end, the options are prioritized based on the difference between the number of victories $\sum^{\mathrm{C}}$ and the number of defeats $\sum^{\mathrm{R}}$, and the outcome is determined by the difference between the defeats and victories (Pour Taheri, 2015: 184). Finally, ARC GIS10.2 is used to draw the spatial distribution map of the cities.

Table 1. Research indices and criteria

(Data Source: 2015 Statistical Yearbook and 2016 Population and Housing Census)

\begin{tabular}{|c|c|}
\hline \begin{tabular}{|c|} 
Index \\
(indicator)
\end{tabular} & Criterion \\
\hline Economic & 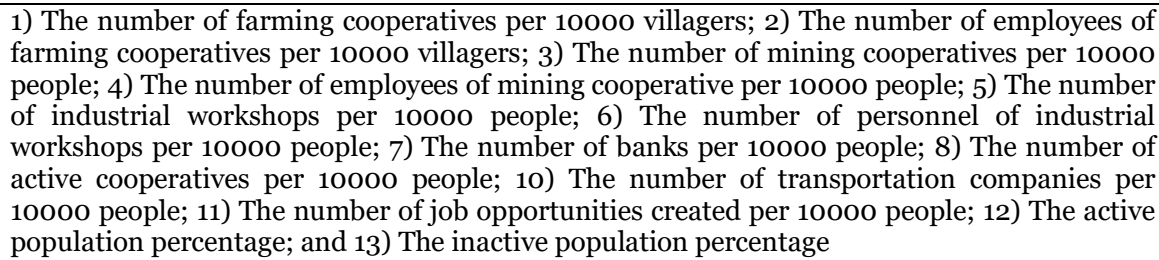 \\
\hline Educational & $\begin{array}{l}\text { 1) Percentage of female villagers' literacy; 2) Percentage of male villagers' literacy; 3) Percentage } \\
\text { of urban women's literacy; 4) Percentage of literacy of urban men; 5) The number of trained } \\
\text { personnel per } 10000 \text { people; 6) Percentage of users of educational-cultural services; 7) The } \\
\text { number of kindergartens per 10ooo children; 8) The number of elementary schools per } \\
\text { 1000o people; 9) The number of first and second grade high schools per 10ooo people }\end{array}$ \\
\hline Infrastructural & 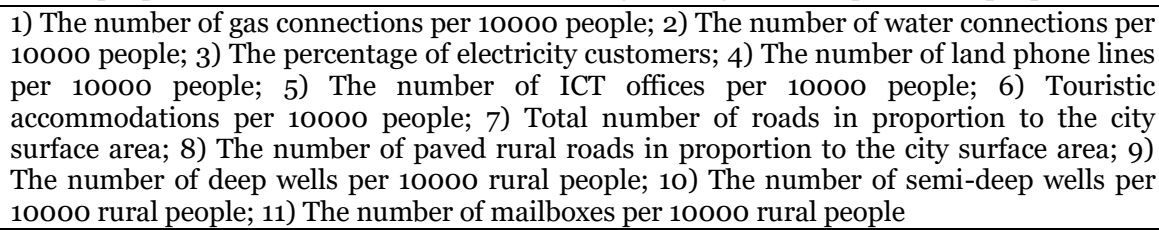 \\
\hline $\begin{array}{l}\text { Health and } \\
\text { treatment }\end{array}$ & 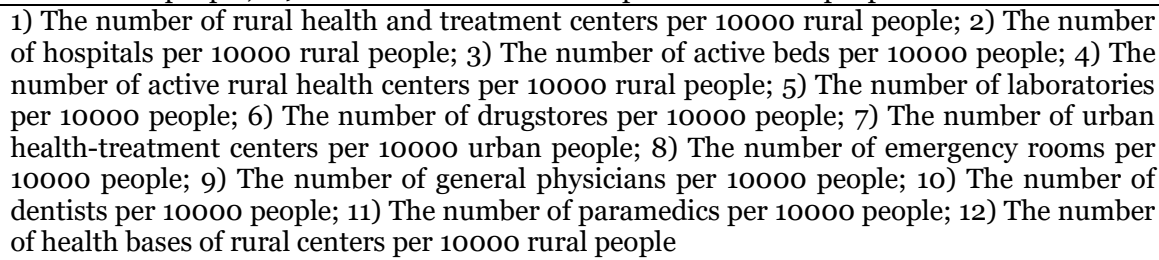 \\
\hline $\begin{array}{l}\text { Welfare- } \\
\text { social }\end{array}$ & $\begin{array}{l}\text { 1) Rehabilitation centers per } 10000 \text { people; 2) Number of counseling centers covered by the } \\
\text { prevention deputy of the Welfare Organization per 10ooo people; 3) The number of people } \\
\text { covered by the social security insurance (per 10oo people); 4) The number of training courses } \\
\text { offered by Hilal Ahmar per } 10000 \text { people; 5) The number of rescue teams per } 1000 \text { people; } \\
\text { 6) The number of clients per } 1000 \text { people; 7) The number of therapeutic service providers } \\
\text { and insurance service provides per } 10000 \text { people; } 8 \text { ) The percentage of pensioners. }\end{array}$ \\
\hline Cultural & $\begin{array}{l}\text { 1) The percentage of postal items exported from this province; 2) The percentage of postal } \\
\text { items exported to other cities of the province; 3) The number of cinemas per } 10000 \\
\text { people; 4) The number of printing houses per 100oo people; 5) The number of public } \\
\text { libraries per } 1000 \text { people; 6) The percentage of the library members; 7) The number of } \\
\text { public libraries for the literate population }\end{array}$ \\
\hline
\end{tabular}

\section{STUDY AREA}

Kurdistan Province has an area of $28200 \mathrm{~km}^{2}$, which accounts for $0.71 \%$ of the country's area. It is located at $23^{\circ} 45^{\prime \prime}-36^{\circ} 28^{\prime \prime} \mathrm{N}$ latitude and $45^{\circ} 34^{\prime \prime}-48^{\circ} 14^{\prime \prime E}$ longitude. This province is located in the hillside and the scattered plains of the Central Zagros. It reaches West Azerbaijan and Zanjan provinces in the north and Hamedan and Zanjan provinces in the east. In the south it shares borders with Kermanshah Province and reaches Iraq in the west. Kurdistan Province also has a 200-km border with Iraq. Based on the latest national divisions, it is composed of 10 cities, 31 districts, 86 Rural complex, 1697 populated 
villages, and 187 deserted villages. Moreover, based on the 2016 Population and Housing Census, this province has a population of 1603011 people, $66 \%$ of whom reside in urban regions, and $34 \%$ reside in the rural regions. The population density of this province is 51.2 inhabitants $/ \mathrm{km}^{2}$. The figure depicts the position of Kurdistan Province in Iran.

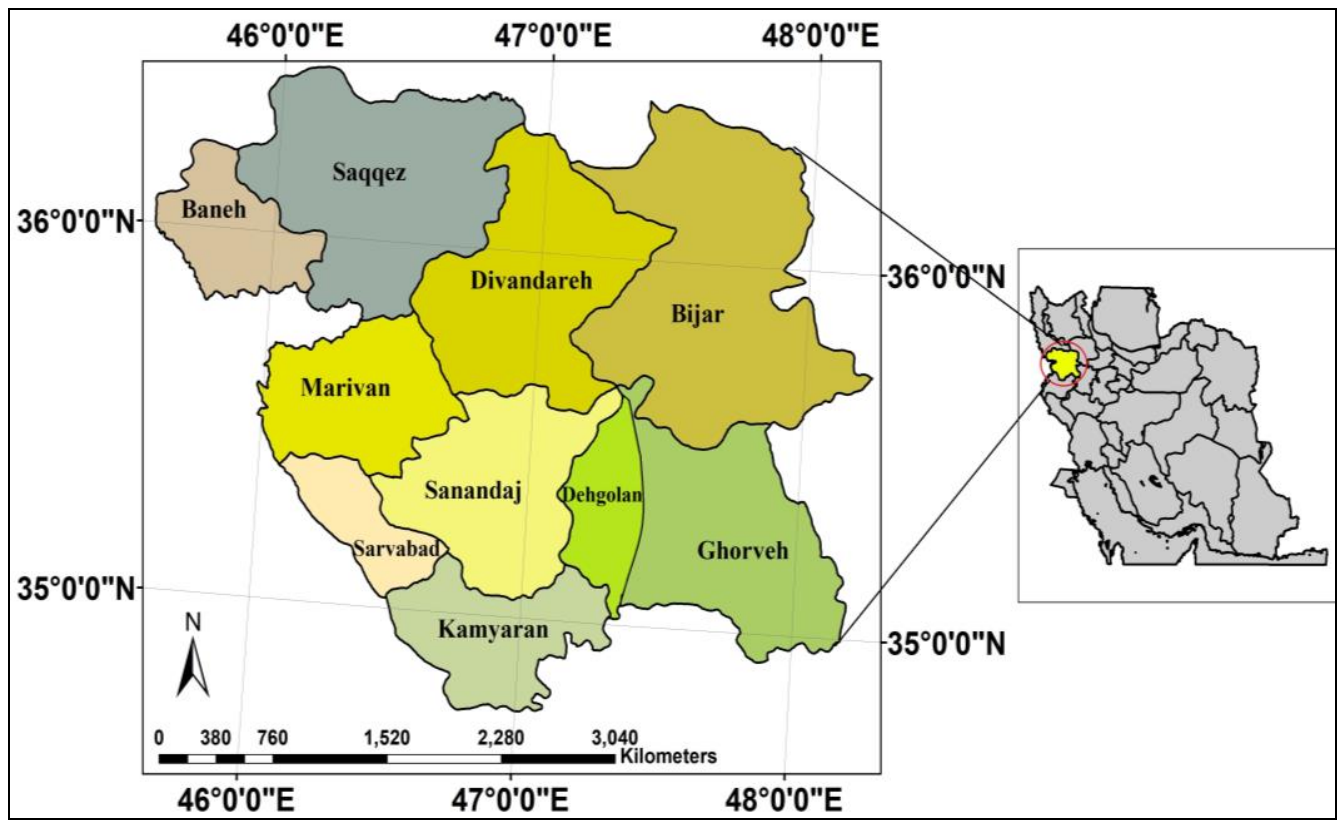

Figure 1. Geographical location of the study area

\section{FINDINGS AND RESULTS}

Based on the research objective, the levels of development of cities of Kurdistan Province were determined using the decision-making techniques. Hence, first the Shannon entropy was used to assign a weight to each criterion. As seen in Table (2), the criteria have different weights. Among the economic indices, the inactive population criterion has the highest weight, which is 0.072. Among the educational criteria, the percentage of urban men's literacy has the highest level of importance $(=0.0317)$.

On the other hand, the number of books in the public libraries to the number of literate people has the highest weight $(=0.1169)$ among the cultural indices. Of the 12 infrastructural and fundamental criteria, the number of electricity consumers has the highest level of importance (with 0.0547). As regards the health and treatment index, the number of paramedics displays the highest level of importance (with 0.0002) as compared to the other criteria. Finally, the number of people with social insurance coverage stages the highest importance among the welfare-social indices with a weight of 0.0526 (Table 2). After assigning weights to the research criteria, the aforesaid techniques were used to prioritize the cities of this province. In VIKOR, the VIKOR index, which is the final score of each criterion, is calculated. Q shows the final rank of each village among the 61 study criteria. This value varies between $\mathrm{o}$ and 1 . As the value approaches zero, the development level increases, but as it approaches one, it is indicative of underdevelopment. Hence, the findings from VIKOR indicate that Sanandaj City has the highest level of development $(=0.000)$, while Divandarreh City has the lowest quality of development indices as compared to the other cities (=1.00). 
Analyzing the Regional Development of Kurdish Border Cities of Iran Using Sustainable Urban Development Indices (Study Area: Kurdistan Province)

Table 2. The weights of the study criteria based on Shanon entropy (Jackson, 2017)

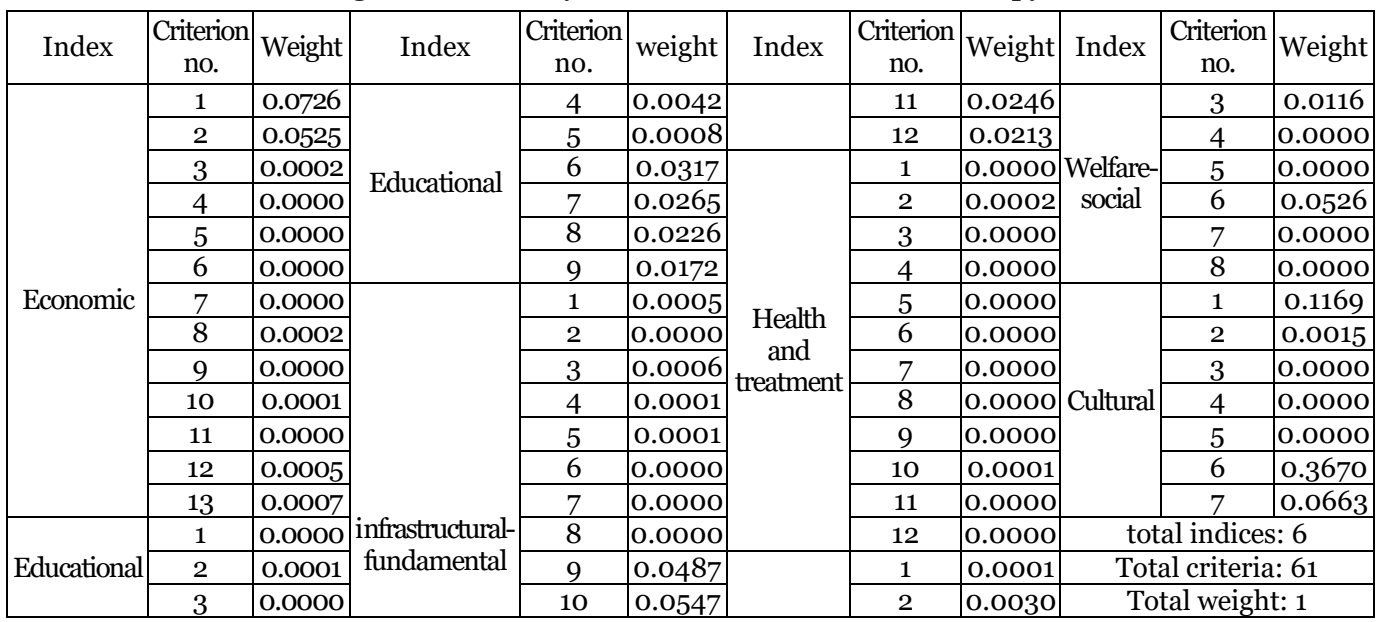

Considering the final results from TOPSIS, the $\mathrm{C}^{*}$ ideal shows the final rank of each city among the 61 criteria. A larger rank shows a higher priority, and thus Sanandaj City has the highest rank, whereas Sarv Abad has the lowest rank. The other technique used in this research to rank the cities by the degree of development was the SAW technique. In this method, if the options approach one, the city is in better condition. Hence, the findings from this technique suggest that Sanandaj City has the highest degree of development as compared to the other cities (=0.877), whereas Sarv Abad City $(=0.331)$ has the lowest degree of development as compared to the other 9 cities (Table 3 ).

Table 3. Ranking of Kurdistan cities using the decision-making techniques

\begin{tabular}{|c|c|c|c|c|c|c|c|c|}
\hline City & $\begin{array}{c}\text { VIKOR score, } \\
\text { Q value }\end{array}$ & Rank & City & $\begin{array}{c}\text { TOPSIS score, } \\
\text { C }^{*} \text { value }\end{array}$ & Rank & City & $\begin{array}{c}\text { SAW } \\
\text { score }\end{array}$ & Rank \\
\hline Sanandaj & 0.000 & 1 & Sanandaj & 0.983 & 1 & Sanandaj & 0.877 & 1 \\
\hline Baneh & 0.219 & 2 & Baneh & 0.655 & 2 & Baneh & 0.679 & 2 \\
\hline Marivan & 0.470 & 3 & Saqqez & 0.555 & 3 & Bijar & 0.667 & 3 \\
\hline Bijar & 0.473 & 4 & Marivan & 0.527 & 4 & Marivan & 0.599 & 4 \\
\hline Saqqez & 0.552 & 5 & Bijar & 0.494 & 5 & Saqqez & 0.598 & 5 \\
\hline Gharveh & 0.632 & 6 & Divan Darreh & 0.425 & 6 & Gharveh & 0.569 & 6 \\
\hline Dehgolan & 0.747 & 7 & Gharveh & 0.415 & 7 & Kamyaran & 0.538 & 7 \\
\hline Kamyaran & 0.841 & 8 & Dehgolan & 0.405 & 8 & Dehgolan & 0.538 & 8 \\
\hline Sarv Abad & 0.935 & 9 & Kamyaran & 0.393 & 9 & Divan Darreh & 0.516 & 9 \\
\hline Divan Darreh & 1.000 & 10 & Sarv Abad & 0.030 & 10 & Sarv Abad & 0.331 & 10 \\
\hline
\end{tabular}

As seen in Table 4, each city of Kurdistan Province has a different position according to each ranking technique. Hence, Copeland technique was used to secure the consistency of the ranks (Alavi, 2011). This technique uses pairwise comparisons for decision making. The final outcome is calculated based on the difference between the victories and defeats (Table 4). The results from Copeland technique suggest that Sanandaj City is privileged in terms of the study indices, yet Sarv Abad is deprived of development (i.e. the lowest level of development) (Table 5). Finally, the spatial distribution map of the development levels of the cities of Kurdistan Province was prepared using the results from Copeland (Yfantidou \& et al, 2018), (Figure 2). 
Table 4. Integration of the results from different models using Copeland (Alavi, 2011)

\begin{tabular}{|c|c|c|c|c|c|c|c|c|c|c|c|}
\hline City & Baneh & Bijar & $\begin{array}{c}\text { Diavn } \\
\text { Darreh }\end{array}$ & Saqqez & Sanandaj & Gharveh & Kamyaran & Marivan & $\begin{array}{c}\text { Sarv } \\
\text { Abad }\end{array}$ & Dehgolan & $\Sigma \mathrm{C}$ \\
\hline Baneh & & $\mathrm{M}$ & $\mathrm{M}$ & $\mathrm{M}$ & $\mathrm{X}$ & $\mathrm{M}$ & $\mathrm{M}$ & $\mathrm{M}$ & $\mathrm{M}$ & $\mathrm{M}$ & 8 \\
\hline Bijar & $\mathrm{X}$ & & $\mathrm{M}$ & $\mathrm{X}$ & $\mathrm{X}$ & $\mathrm{M}$ & $\mathrm{M}$ & $\mathrm{X}$ & $\mathrm{M}$ & $\mathrm{M}$ & 5 \\
\hline Divan Darreh & $\mathrm{X}$ & $\mathrm{X}$ & & $\mathrm{X}$ & $\mathrm{X}$ & $\mathrm{X}$ & $\mathrm{X}$ & $\mathrm{X}$ & $\mathrm{M}$ & $\mathrm{X}$ & 1 \\
\hline Saqqez & $\mathrm{X}$ & $\mathrm{X}$ & $\mathrm{M}$ & & $\mathrm{X}$ & $\mathrm{M}$ & $\mathrm{M}$ & $\mathrm{X}$ & $\mathrm{M}$ & $\mathrm{M}$ & 5 \\
\hline Sanandaj & $\mathrm{M}$ & $\mathrm{M}$ & $\mathrm{M}$ & $\mathrm{M}$ & & $\mathrm{M}$ & $\mathrm{M}$ & $\mathrm{M}$ & $\mathrm{M}$ & $\mathrm{M}$ & 9 \\
\hline Gharveh & $\mathrm{X}$ & $\mathrm{X}$ & $\mathrm{M}$ & $\mathrm{X}$ & $\mathrm{X}$ & & $\mathrm{M}$ & $\mathrm{X}$ & $\mathrm{M}$ & $\mathrm{M}$ & 4 \\
\hline Kamyaran & $\mathrm{X}$ & $\mathrm{X}$ & $\mathrm{M}$ & $\mathrm{X}$ & $\mathrm{X}$ & $\mathrm{X}$ & & $\mathrm{X}$ & $\mathrm{M}$ & $\mathrm{X}$ & 2 \\
\hline Marivan & $\mathrm{X}$ & $\mathrm{M}$ & $\mathrm{M}$ & $\mathrm{M}$ & $\mathrm{X}$ & $\mathrm{M}$ & $\mathrm{M}$ & & $\mathrm{M}$ & $\mathrm{M}$ & 7 \\
\hline Sarv Abad & $\mathrm{X}$ & $\mathrm{X}$ & $\mathrm{X}$ & $\mathrm{X}$ & $\mathrm{X}$ & $\mathrm{X}$ & $\mathrm{X}$ & $\mathrm{X}$ & & $\mathrm{X}$ & $\mathrm{O}$ \\
\hline Dehgolan & $\mathrm{X}$ & $\mathrm{X}$ & $\mathrm{M}$ & $\mathrm{X}$ & $\mathrm{X}$ & $\mathrm{X}$ & $\mathrm{M}$ & $\mathrm{X}$ & $\mathrm{M}$ & & 3 \\
\hline LR & $\mathrm{1}$ & 3 & 8 & 3 & $\mathrm{O}$ & 4 & 7 & 2 & 8 & 6 & \\
\hline
\end{tabular}

Table 5. Ranking of the cities of Kurdistan Province using Copeland

\begin{tabular}{cccccc}
\hline City & $\mathbf{\Sigma C}$ & $\mathbf{\Sigma R}$ & $\mathbf{\Sigma C}-\mathbf{\Sigma R}$ & Priority & Development status \\
Sanandaj & 9 & $\mathbf{0}$ & 9 & 1 & \\
Baneh & 8 & 1 & 7 & 2 & Developed \\
Marivan & 7 & 2 & 5 & 3 & \\
Saghez & 6 & 4 & 1 & 4 & \\
Bijar & 5 & 4 & 1 & 5 & \\
Gharveh & 4 & 5 & -1 & 6 & \\
Dehgolan & 3 & 6 & -3 & 7 & \\
Kamyaran & 2 & 7 & -5 & 8 & \\
Divan Darreh & 1 & 8 & -7 & 9 & \\
Sarv Abad & 0 & 9 & -9 & 10 & \\
\hline
\end{tabular}



Figure 2: Spatial distribution of the cities of Kurdistan Province by the levels of development

\section{DISCUSSION AND CONCLUSIONS}

The ultimate goal of every planning initiative is to achieve sustainable balanced regional development and make maximum use of the environmental capabilities and the balance in the development process. However, regional developmental disparities caused 
by various historical, natural, social, and economic reasons have resulted in the heterogeneous imbalanced growth of the regions. In addition, access to facilities and proper/accurate zoning are issues that must be prioritized by urban managers. These issues call for precise investigations and examinations because ranking reveals the spatial, social, cultural, and economic differences (Monfaredian \& Sarvetani, 2007). The present research goals were to measure development and rank the cities of Kurdistan Province by the development indices. Six indices, viz. the educational, cultural, economic, infrastructural, welfare, and health/treatment indices, were used in the form of 61 criteria extracted from the aforesaid statistical yearbook and 2016 census. In order to analyze the indices, weights were assigned using Shannon entropy model. The results revealed that the "percentage of the number of the library members" criterion (with a weight of 0.3670 ) had the highest level of importance. The results from the TOPSIS, VIKOR, and SAW techniques also indicated that Sanandaj and Baneh cities enjoyed higher levels of development according to all of the three techniques, while the other cities attained lower ranks with varying priorities. Hence, Copeland technique was employed to secure the consistency of the results. The examination of the spatial organization of Kurdistan Province indicated that despite its large potentials, this region suffers from spatial imbalance. The results also suggested that only Sanandaj City is developed, and the high per capita indices and criteria are among the factors influencing the development of this city as compared to the other cities. In other words, the centralization of facilities, services, and activities has deprived the other cities of development, and the development indices lack congruity on the city level. On the other hand, it could be stated that the development of the core-periphery relations and the attraction of investments to the capital of this province as well as the development caused by the attraction of investment from the peripheries to the core have maximized the bipolarity of the facilities and the number of expert human forces moving from the peripheries to the core.

As a result, four cities, namely Bijar, Saghez, Baneh, and Marivan, are halfdeveloped, while the other five cities (viz. Gharveh, Dehgolan, Kamyaran, Sarv Abad, and Divan Darrreh) are deprived of development due to their negative results. The inadequacy of the economic indices and the lack of proper access to the urban and rural roads are among the factors hindering the development of these cities. On the other hand, the shortage or the lack of equipped laboratories, central rural health centers, and cultural facilities have contributed to the negative development of these cities, resulting in the temporary or permanent migrations from the city centers to the capital of this province. Hence, disparities can be avoided by planning the fair distribution of the services, which calls for a decrease in the differences between cities in terms of development indices. Therefore, concern for regional planning, avoidance of district-based planning, and adherence to balanced policies for the creation of equal opportunities and provision access to different types of development indices in all cities of this province are essential.

In sum, it could be stated that the cities of Kurdistan Province are not in a good place in terms of the development indices and most of them are either semi-privileged (half-developed) or deprived of development. Hence, it is necessary to set the scene for the growth and development of this province by lending a deep insight into the limitations on the study cities and stressing the criteria and the more underdeveloped cities. This is because there is a lack of congruity between the population density and the distribution of facilities and services. Furthermore, development relies on success in all dimensions such as the economic, spatial, cultural, educational, and health dimensions. On the other hand, the unfettered access to diverse human and environmental facilities and the proper utilization of these resources are indicative of higher levels of regional 
development. This reflects the necessity of valuing the policies for the elimination of deprivation and establishment of regional balance, because the planning approach governing the country and the centralized planning system have affected this province in the past years by increasing the regional disparities.

\section{Suggestions}

The following solutions are proposed for enhancing the development of the cities of Kurdistan Province in view of the research findings:

- Developing and improving access to the roads as the bottlenecks of development in order to establish balance in the spatial and communicative organization of cities, which lack proper access to the roads.

- Increasing and improving the efficiency of the active population of the province and creating sustainable employment in the deprived and underprivileged cities.

- Encouraging and fostering public and private investments with the aim of improving the development indices and diversifying the sources of income in the deprived cities.

- Prioritizing the deprived cities (the majority of the cities) in the distribution of credit and budget in the provincial development polices and plans.

- Local authorities and the government are obliged to conduct planning and take substantial measures to improve the development and condition of this province as regards the infrastructural and health-treatment indices considering the low levels of these indices in all cities of this province.

- Improving the educational indices, literacy, and educational coverage in the deprived/far-off cities and villages.

- Improving access to the cultural centers, constructing educational and academic centers in the deprived cities, and founding/running reputable libraries in the cities and villages.

- Valuing the provincial plans to secure the decentralization of the cultural facilities and services in the capital of this province and guarantee the proper distribution of these facilities and services in the other cities.

\section{REFERENCES}

Alavi, F. (2011). Urban Sustainability Assessment and Ranking of Cities. Computers, Environment And Urban Systems, Vol 64, Pp 254-265.

Anabestani, A.S., Rosta, M., Avarideh, A., \& Sayadi Abgeli, M. (2014). Comparative Comparison of Rural Levels of Equity Using Morph Ratio and Feature Coefficient, Case Study: Meymand Section. Firoozabad County, Geography and Urban Planning, Zagros Landscape, Year 6, No. 19, pp. 119-99.

Antoan, N. (2006). Cardoo and Faletts Dependency and Development in Latin America. Norderstedt: Aflame.

Badiali, F, Ilieş, D.C., \& Castaldini, D. (2018). A tale of a city, through its urban landscape and cultural heritage in the heart of europe: the case study of oradea city (Romania). GeoJournal of Tourism and Geosites, Year XI, no. 1, vol. 21, p. 88- 102.

Badri, A., Akbarian Ronizzi, S.R., \& Javaheri, H. (2006). Determination of Developmental Levels of Rural Areas in Kamyaran City. Geographical Research, No. 82, pp. 126-116.

Barrera, P.P., Carreon, J.R., Hugo, J., \& Beor, D. (2018). A multi-level framework for Metabolism in Urban Energy Systems from an Ecological Perspective Resources. Conservation \& Recycling, No 132, Pp 230-238.

Carreon, J.R., \& Worrell, E. (2018). Urban Energy Systems Within the Transition to Sustainable Development. A research agenda for urban metabolism, resources. Conservation \& Recycling, No 132, Pp 285-266.

Dadashpour, H., \& Molody, J. (2011). An Analysis and Analysis of Urban Hierarchy Structure in Ardebil Province. Geographical Space, Year 11, No. 34, pp. 131-102.

Dehghani, M., \& Razmi Shavazi, A. (2011). Determination of degree of development of cities in Yazd province and modeling of optimal allocation of capital asset credits in terms of city. Moderator: Tivaye Desert Arshad Study Type: Research Designer, Seyed Mojtaba Hosseinipour Ardakani. 
Analyzing the Regional Development of Kurdish Border Cities of Iran Using Sustainable Urban Development Indices (Study Area: Kurdistan Province)

Ela. R., \& Schwarrtzb, D. (2006). Review Regional Development as a policy for growth with equity: The State of Ceara (Brazil) As A Model. Progress In Planning, Vol. 65, No. 3, Pp. 131-199.

Fragkias, M., Lobo, J., Strumsky, D., \& Seto, K.C. (2013), Does Size Matter? Scaling of CO2 Emissions and U.S. Urban Areas. Plos One 8, E64727. Http://Dx.Doi.Org/10.1371/ Journal. Pone.0064727.

Ghaedi Rahmati, S., Mostofi Al-Mamaleki, R., \& Barari, M. (2013), Analysis of Development Indices and Leveling of Rural Areas of Yazd Province. Geography and Development, No. 30, pp. 86-71.

Harvey, Ja. (1996). Urban Land Economic, London.

Hataminezhad, H., Zaeri, M., Hajilo, M., \& Valizadeh, Z. (2017). Leveling the areas of Mashhad city based on the level of utilization of urban services using the Wikim project. Geographical Space, Year 17, No. 57, pp. 17-1.

Haughton, G., \& Counsell, D. (2004). Regions, Spatial Strategies and Sustainable Development. 1th Ed, London, Routledge.

Husseinzaeh Dalir, K. (2013). Regional Planning. Tehran. p. 90.

Jackson, M. (2017). Human Resource Inequalities at The Base of India's Public Health Care System. Health Place, Vol, 23, pp. 26-32.

Lotfi, P., \& Shabani, M. (2013). A Composite Model for Regional Development Ranking, Case Study: Mazandaran Provincial Healthcare Department, Geosciences Applied Research Journal, Year 13, Issue 28, pp. 30-7.

Michael, F. (2014). Review of Urban Sustainability Indicators Assessment-Case Study Between Asian Countries. Habitat International, No 44: 491-500.

Mirzakhani, B., \& Brendak, F. (2014). Levels of Development in Ardebil Province Cities. Geography and Environmental Studies, Third Year, No. 11, pp. 90-79.

Montazer Torbati, J. (2008), Analysis of Spatial Inequality in the Region, Case Study: Razavi Khorasan Province, Master's Thesis for Urban and Regional Planning, Supervisor: Mohammad Hosein Sharifzadegan, Faculty of Architecture and Urban Planning, Shahid Beheshti University.

Nazmfar, H., Bakhtar, S., \& Alavi, S. (2015). Rated Development Levels in Rural Areas, Case Study: Kermanshah Provinces, Geography and Environmental Studies, Vol. 4, No. 14, pp. 192-181.

Nemati, M., Nozari, A., \& Abbasi, Z. (2014). An Analysis of the Physical Developmental Condition of the Three Areas of Shushtar City Using the AHP-TOPSIS Combined Model. Geography and Urban Planning of the Zagros Outlook, Vol. 6, No. 20, pp. 74-59.

Pourtaheri, M.M. (2015). Application of Multi-Attribute Decision Making Methods in Geography, Tehran, p. 184.

Saeedi, A. (1998), The Basics of Rural Geography, Side Publishing, Tehran.

Safaypour, M., \& Sabah Pour Madoun, F. (2016). Leveling the cities of Khuzestan province based on cultural development indicators using Gray Relationship Analysis. Social Development Studies, vol. 8, No. 3, pp. 18-7.

Salimi, H. (2012). Beginning and Doing Theory of Affiliation, Social Sciences, No. 65, pp. 2206-169.

Sassanpur, F. (2011). The Basics of Sustainable Development of Metropolises with Emphasis on Metropolitan Tehran, Tehran. Center for Urban Planning Studies, Tehran.

Sassanpur, F., Mostafavi Sahib, A., \& Mozaffar, M. (2015), Analysis of Spatial Inequality in Utilization of Urban Services, Case Study: 22 Towns of Sanandaj. Urban Planning and Research, Vol. 6, No. 23, pp. 114-95.

Soleimani, A., Aftab, A., \& Sheikhahmadi, A. (2016). Analysis, evaluation and ranking of the levels of urban areas in Urmia. Urban Management Studies, Eighth, No. 25, pp. 90-79.

Taghvayi, M., \& Ghaedrahmati, S. (2006). Analysis of Regional Development inequalities in Iran. Human Geography Research, No. 78, pp. 168-153.

Taghvayi, M., Verasati, H., \& Sheikhibiglo, R. (2011). Analysis of Regional Development inequalities in Iran. Human Geography Research, No. 78, pp. 168-153.

Tavakkoli, J., Mirkhadad, A., \& Ebrahimi, M. (2014). Measuring the Levels of Socio-Economic Development of Villages in the Central District of Kohdasht, Rural Studies, Vol. 5, No. 1, pp. 235-213.

Venkatesh B. S. (2002), Problems and Prospects of Development of Backward Regions: A Study of Karnataka State, Thesis of Doctor of Philosophy in Economics, Under Supervision of Hemlata Rao, Bangalore University, Bangalore.

Yfantidou, G., Nikou, M., \& Matsouka, O. (2018). Winter tourism in Greece: An approach to tourist behavior and needs. GeoJournal of Tourism and Geosites. Year XI, no. 1, vol. 21, p. 74- 87.

Yu, L., Hou, X., Gao, M., \& And Shi, P. (2010). Assessment of Coastal Zone Sustainable Development: A Case Study of Yantai, China. Ecological Indicators, No. 10, PP. 1218-1225.

Zareh, B., \& Zandilak, A. (2011). The Study of the Relationship between the Level of Economic-Social Development and the Rate of Harsh Crimes Among Provinces. Social Studies in Iran, Volume V, No.3, pp. 123-97.

*** Statistical Yearbook of Kurdistan Province. (2015). Management and Planning Organization of Kurdistan Province.

*** UN. (2011). City planning and this challenge in developing countries. UN Publication, 65, England.

*** UNEP (United Nations Environment Programmed). (2015). Global Initiative for Resource Efficient Cities. UNEP Division of Technology, Industry and Economics.

*** Population and Housing Census. (2016), Statistics Center of Iran.

*** Population and Housing Census. (2016). Management and Planning Organization of Kurdistan Province.

Submitted:

15.08.2018
Revised:

19.11.2018
Accepted and published online 21.11.2018 